\title{
Kajian Ragam dan Periode Penyimpanan Kombinasi Air Rebusan Daun Sirih dan Kayu Siwak Terhadap Pertumbuhan Streptococcus mutans
}

\author{
YUSTIN NUR KHOIRIYAH ${ }^{1}$, SRI MURWANINGSIH ${ }^{1}$ \\ ${ }^{1}$ Politeknik Kesehatan Tanjungkarang \\ J1. Soekarno Hatta No. 1 Bandar Lampung, Lampung. 35145 \\ Email: yustinkhoiriyah@ poltekkes-tjk.ac.id
}

(diterima: 7 Desember 2017; direvisi: 17 Januari 2018; diterima: 2 Februari 2018; dipublikasi online: 28 Februari 2018)

\begin{abstract}
The community for maintaining healthy teeth and mouth has used betel and siwak wood plants. However, the benefits of a combination of both plants have not been widely known. The main output of this research was to know the utilization of a combination of betel leaf water and siwak wood as a mouthwash candidate. Combination of boiled water of both plants is a processed product, which has a shelf life. As a mouthwash product that is stored for a long time allegedly decreased the level of usefulness. One parameter of usability level to be observed in this study was the inhibition of Streptococcus mutans, the bacteria that cause dental caries. This study was laboratory experimental research, and use post test only with control group design with Cross-Sectional approach. Data analyzed by T-test and ANOVA followed by LSD test. Inhibition zone of boiled water stored at room temperature was smaller than cold temperature. However, T-test results showed that the diameter of inhibition zone of boiled water stored at room temperature and the cold temperature was not significantly different ( $\mathrm{p}$-value $=0,586>0,05)$. Significantly decreased drag zone diameters occurred in a combination of boiled water stored for 16 and 18 days. Then the storage variety did not have a real effect, while the storage period significantly affects the inhibition power of boiled water in the growth of Streptococcus mutans.
\end{abstract}

Keywords: betel, combination, siwak, storage, Streptococcus mutans

\section{INTISARI}

Masyarakat telah lama menggunakan sirih dan siwak untuk menjaga kesehatan gigi dan mulut. Keluaran utama penelitian ini adalah mengetahui pemanfaatan kombinasi air rebusan daun sirih dan kayu siwak sebagai kandidat obat kumur. Kombinasi air rebusan kedua tanaman tersebut merupakan suatu produk olahan yang memiliki umur simpan. Sebagai produk obat kumur, kombinasi air rebusan daun sirih dan kayu siwak yang disimpan dalam kurun waktu lama, diduga mengalami penurunan tingkat kegunaannya. Satu parameter tingkat kegunaan yang diamati pada penelitian ini adalah daya hambat terhadap Streptococcus mutans, bakteri penyebab karies gigi. Jenis penelitian ini eksperimental laboratories menggunakan rancangan post test only with control group design dengan pendekatan Cross Sectional. Analisis data menggunakan T test dan ANOVA yang dilanjutkan dengan uji LSD. Zona hambat kombinasi air rebusan yang disimpan pada suhu ruang $\left(25 \pm 1^{\circ} \mathrm{C}\right)$, lebih kecil dibandingkan suhu dingin $\left(0-8^{\circ} \mathrm{C}\right)$. Namun hasil $\mathrm{T}$ test menunjukkan bahwa diameter zona hambat kombinasi air rebusan yang disimpan pada suhu ruang $\left(25 \pm 1^{\circ} \mathrm{C}\right)$ dan suhu dingin $\left(0-8^{\circ} \mathrm{C}\right)$ tidak berbeda nyata. Penurunan diameter zona hambat yang bermakna terjadi pada kombinasi air rebusan yang disimpan selama 16 dan 18 hari. Maka ragam penyimpanan tidak berpengaruh nyata, sedang periode penyimpanan berpengaruh nyata terhadap daya hambat kombinasi air rebusan pada pertumbuhan Streptococcus mutans.

Kata kunci: kayu siwak, kombinasi, penyimpanan, sirih, Streptococcus mutans 


\section{PENDAHULUAN}

Indonesia adalah negara agraris yang kaya akan sumber daya alam yang dapat dimanfaatkan untuk memenuhi berbagai kebutuhan masyarakat, misalnya pemanfaatan tanaman sebagai bahan baku produk makanan, kosmetik dan pewarna. Peluang untuk mendapatkan senyawa/obat antibakteri dari bahan alam juga lebih memungkinkan (Sumiati, 2014).

Tanaman sebagai salah satu sumber bahan baku alami, yang penggunaannya cenderung lebih disukai dibanding bahan sintetis, meskipun mempunyai kelemahan dalam hal stabilitas mutu bahan. Hal tersebut berkaitan dengan semakin sadarnya masyarakat akan kesehatan dengan memilih bahan alami yang tidak berbahaya.

Sirih merupakan salah satu tanaman yang sejak dahulu telah dimanfaatkan oleh masyarakat, terutama dengan mengunyah daun atau buahnya bersama gambir, pinang, dan kapur. Sirih mempunyai berbagai khasiat dan manfaat terutama sebagai obat-obatan herbal. Daun Sirih digunakan sebagai anti sariawan, anti batuk, adstringen dan antiseptik, bau mulut, bisul, abses, sembelit, konjungtivitis, sakit kepala, hysteria, gatal, mastitis, mastoiditis, keputihan, kurap pembengkakan gusi, rematik, abrasi, dan luka (BPOM RI, 2012; Chopra et al., 1956; DEPKES RI, 1980).

Sedangkan siwak atau miswak dikenal dengan nama ilmiah (Salvadora persica). Kayu ini biasa digunakan untuk menggantikan fungsi sikat gigi dan pasta gigi. Mayoritas orang-orang di negara-negara muslim menggunakannya untuk menyikat gigi seharihari (Ummuhanik, 2011). Siwak adalah tongkat kayu yang ukurannya sekitar 8 inci panjang dan selebar jari. Ujung kayu siwak biasanya dikunyah agar serat terpisah menjadi seperti kuas. Etika Islam kontemporer, di mana literatur fatwa (legal responsa) hanyalah satu contoh, siwak telah mendapatkan kembali pengakuan dan sering dipuji sebagai cara yang lebih disukai untuk perawatan gigi (Risplerchaim, Vardit., 1992).

Studi yang dilakukan oleh Al-Lafi dan Ababneh (1995) dalam Adrianto (2012) pada siwak atau miswak membuktikan bahwa pasta gigi siwak atau miswak lebih baik dalam mencegah penyakit gusi. Kayu siwak menunjukkan bahwa siwak mengandung mineral-mineral alami yang dapat membunuh bakteri, menghilangkan plaque, mencegah gigi berlubang serta memelihara gusi.

Ekstrak siwak dapat menghambat pertumbuhan bakteri patogen Aggregatibacter actinomycetemcomitans sebagai salah satu penyebab penyakit periodontal dengan konsentrasi terbesar yaitu 50\% dan konsentrasi terkecil yaitu 3,125\% (Djais dan Tope, 2017).

Berdasarkan uraian tersebut menunjukkan bahwa kedua tanaman memiliki manfaat yang besar dalam menjaga kesehatan gigi dan mulut. Namun, manfaat kombinasi kedua tanaman belum banyak diketahui. Keluaran utama penelitian ini adalah mengetahui pemanfaatan kombinasi air rebusan daun sirih dan kayu siwak sebagai kandidat obat kumur. Kombinasi air rebusan kedua tanaman tersebut merupakan suatu produk olahan yang memiliki umur simpan. Jika melewati waktu tersebut, produk dapat dikatakan tidak layak digunakan. Hal ini dikarenakan produk mengalami perubahan baik fisika, kimia maupun mikrobiologis seperti kenampakan dan cita rasa. Perubahan-perubahan tersebut akan menurunkan tingkat kegunaan produk tersebut dan akan diperburuk dengan cara penyimpanan yang salah. Apabila kombinasi air rebusan daun sirih dan kayu siwak sebagai produk obat kumur, disimpan dalam kurun waktu lama, diduga mengalami penurunan tingkat kegunaannya. Satu parameter tingkat kegunaan yang akan diamati pada penelitian ini adalah daya hambat terhadap Streptococcus mutans, bakteri penyebab karies gigi.

Tujuan umum penelitian ini adalah untuk mengetahui pengaruh ragam dan periode penyimpanan kombinasi air rebusan daun sirih dan kayu siwak terhadap daya hambat pertumbuhan Streptococcus mutans. Khususnya untuk mengetahui ragam penyimpanan kombinasi air rebusan daun sirih dan kayu siwak yang dapat mempertahankan daya hambatnya terhadap Streptococcus mutans serta mengetahui periode penyimpanan kombinasi air rebusan daun sirih dan kayu siwak. 


\section{METODE}

Jenis penelitian ini adalah penelitian eksperimental laboratoris karena penelitian ini dilakukan dengan prosedur laboratorium, serta menggunakan rancangan post test only with control group design dengan pendekatan Cross Sectional.

Bahan uji yang digunakan adalah kayu siwak dan daun sirih. Kriteria bahan uji yaitu: kayu siwak memiliki daging kayu berwarna putih dan tebal, dalam kondisi bersih dan telah dikeringkan, daun sirih berwarna hijau dan masih segar. Kedua bahan uji dibuat kombinasi air rebusan.
Streptococcus mutans sebagai subjek penelitian. Kelompok perlakuan terdiri dari 4 (empat) yaitu kontrol positif, kontrol negatif, kombinasi air rebusan disimpan pada suhu 0$8^{\circ} \mathrm{C}$ dan kombinasi air rebusan disimpan pada suhu kamar $\left(25 \pm 1^{\circ} \mathrm{C}\right)$. Jumlah ulangan masingmasing kelompok ialah 6 (enam) ulangan.

Pembuatan Kombinasi Air Rebusan Daun Sirih dan Kayu Siwak Konsentrasi 70\%.

1) Daun sirih dan kayu siwak ditimbang sesuai komposisi berikut ini:

Tabel 1. Kombinasi Air Rebusan Daun Sirih dan Kayu Siwak Konsentrasi 70\%

Konsentrasi air rebusan $(1 \%=1 \mathrm{gram} / 100 \mathrm{~mL})$ $70 \%$
Jumlah daun sirih (gram) $65 \%$ × $70 \mathrm{gram} / 100 \mathrm{~mL}$
Jumlah kayu siwak (gram) $35 \% \times 70 \mathrm{gram} / 100 \mathrm{~mL}$
2) Daun sirih dan kayu siwak yang telah dibersihkan, masing-masing dibilas dengan alkohol $70 \%$, dibilas dengan akuades steril, 3 kali pembilasan, selanjutnya dipotong dengan ukuran 2-3 $\mathrm{cm}$, dipotong dengan alat yang steril dan dilakukan di Bio-safety chamber (BSC).

3) Air sebanyak 3 (tiga) liter dimasukkan dalam bejana dan dipanaskan sampai mendidih (suhu $>90^{\circ} \mathrm{C}$ ).

4) Potongan daun sirih sebanyak 1.365 gram dan kayu siwak sebanyak 735 gram, dimasukkan dalam bejana berisi air mendidih. Pemanasan dalam air selama 30 menit, sambil sesekali diaduk.

5) Penyaringan dilakukan setelah rebusan dingin dengan kertas saring steril dan dilakukan di Bio-safety chamber (BSC).

6) Filtrat air rebusan sebanyak 3 (tiga) liter disimpan dalam botol steril.

7) Penyimpanan dilakukan pada 2 (dua) ragam, yaitu penyimpanan pada suhu ruang $\left(25 \pm 1^{\circ} \mathrm{C}\right)$ dan suhu dingin $\left(0-8^{\circ} \mathrm{C}\right)$.

Pembuatan Suspensi Streptococcus mutans. Biakan Streptococcus mutans diambil dengan menggunakan ose steril kemudian dimasukkan ke dalam tabung yang berisi garam fisiologis $(\mathrm{NaCl}$ 0,9\%) hingga mencapai kekeruhan yang sesuai dengan standar $0,5 \mathrm{Mc}$ Farland sebagai suspensi.
Uji Daya Hambat. Pengujian daya hambat dilakukan pada periode penyimpanan: $0,2,5,7,9,11,14,16$, dan 18 hari, dengan prosedur sebagai berikut:

1) Cawan petri disterilkan

2) Medium Mueller Hinton Agar (MHA) dibuat sebagai media bakteri Streptococcus mutans. Metode inokulasi bakteri yaitu metode sebar (spread).

3) Media yang telah diinokulasi bakteri sebanyak 3 (tiga) cawan, masing-masing dibuat sumuran sebanyak 6 (enam) buah. Ketiga media cawan tersebut terdiri dari kelompok kombinasi air rebusan daun sirih dan kayu siwak, kelompok obat kumur/mouthwash komersial (kontrol positif), dan kelompok akuades (kontrol negatif). Setiap sumuran diisi larutan sebanyak $60 \mu \mathrm{L}$ dengan menggunakan mikropipet.

4) Cawan petri tersebut diinkubasi pada suhu $37^{\circ} \mathrm{C}$ selama 48 jam.

5) Untuk mengetahui daya hambat sampel dilakukan pengukuran zona bening pada permukaan medium nutrien agar disekitar sumuran dengan menggunakan jangka sorong.

Analisis data menggunakan uji One Way ANOVA digunakan untuk membandingkan seluruh kelompok perlakuan, kemudian akan dilanjutkan dengan Post Hoc Test yaitu dengan 
menggunakan uji LSD (Least Significant Difference) untuk membandingkan antar kelompok perlakuan apakah berbeda secara signifikan atau tidak.

\section{HASIL}

Data pengaruh ragam dan periode penyimpanan kombinasi air rebusan daun sirih dan kayu siwak terhadap pertumbuhan Streptococcus mutans adalah data primer yang berupa diameter zona hambat/bening.

Tabel 2. Diameter zona hambat pada uji hambat minimum

\begin{tabular}{cccc}
\hline No. & Perlakuan & Konsentrasi & Rata-rata \pm SD \\
\hline 1 & Kontrol negatif (Akuades) & $10-70 \%$ & $0,00 \pm 0,00^{\mathrm{a}}$ \\
\hline \multirow{2}{*}{2} & Kontrol positif (Obat & $10-70 \%$ & $0,00 \pm 0,00^{\mathrm{a}}$ \\
& Kumur Komersial) & $10 \%$ & $0,00 \pm 0,00^{\mathrm{a}}$ \\
\cline { 3 - 4 } & & $20 \%$ & $0,00 \pm 0,00^{\mathrm{a}}$ \\
\cline { 3 - 4 } 3 & & $30 \%$ & $12,00 \pm 1,000^{\mathrm{a}}$ \\
\cline { 3 - 4 } 3 & Kombinasi Air Rebusan & $40 \%$ & $13,33 \pm 0,577^{\mathrm{a}}$ \\
\cline { 3 - 4 } & Daun Sirih dan Kayu & $50 \%$ & $16,00 \pm 1,732^{\mathrm{a}}$ \\
\cline { 3 - 4 } & Siwak & $60 \%$ & $22,33 \pm 2,516^{\mathrm{a}}$ \\
\cline { 3 - 4 } & & $70 \%$ & $27,33 \pm 0,577^{\mathrm{b}}$ \\
\hline
\end{tabular}

Keterangan: angka yang diikuti dengan huruf yang sama pada kolom yang sama menunjukkan tidak berbeda nyata $(n=5, p>0,05)$

Tabel 2 menunjukkan semakin tinggi konsentrasi kombinasi air rebusan daun sirih dan kayu siwak yang diberikan, semakin luas zona bening yang terbentuk. Kelompok perlakuan kombinasi air rebusan daun sirih dan kayu siwak dengan konsentrasi $10-60 \%$ tidak berbeda nyata terhadap kelompok kontrol negatif (akuades) dan kontrol positif (larutan mouthwash komersial). Sedangkan, kelompok perlakuan kombinasi air rebusan daun sirih dan kayu siwak dengan konsentrasi $70 \%$ berbeda nyata dibandingkan kontrol negatif (akuades) dan kontrol positif (larutan mouthwash komersial). Diameter zona hambat kombinasi air rebusan daun sirih dan kayu siwak dengan konsentrasi $70 \%$ sebesar 27,33 $\pm 0,577$.

Tabel 3. Diameter zona hambat pada uji hambat kombinasi air rebusan daun sirih dan kayu siwak dengan ragam dan periode penyimpanan

\begin{tabular}{|c|c|c|c|}
\hline No. & Perlakuan & Periode Penyimpanan & Rata-rata \pm SD \\
\hline 1 & Kontrol negatif (Akuades) & $0-18$ hari & $0,00 \pm 0,00^{\mathrm{a}}$ \\
\hline 2 & $\begin{array}{c}\text { Kontrol positif (Obat Kumur } \\
\text { Komersial) }\end{array}$ & $0-18$ hari & $0,00 \pm 0,00^{\mathrm{a}}$ \\
\hline \multirow{9}{*}{3} & \multirow{9}{*}{$\begin{array}{l}\text { Kombinasi Air Rebusan Daun } \\
\text { Sirih dan Kayu Siwak } 70 \% \\
\left.\text { (suhu ruang } 25 \pm 1^{\circ} \mathrm{C}\right)\end{array}$} & 0 hari & $26,75 \pm 1,258^{\mathrm{c}}$ \\
\hline & & 2 hari & $19,25 \pm 0,500^{c}$ \\
\hline & & 5 hari & $14,75 \pm 0,500^{c}$ \\
\hline & & 7 hari & $14,25 \pm 0,500^{\mathrm{c}}$ \\
\hline & & 9 hari & $13,25 \pm 0,500^{c}$ \\
\hline & & 11 hari & $13,25 \pm 0,500^{\mathrm{c}}$ \\
\hline & & 14 hari & $13,00 \pm 0,000^{c}$ \\
\hline & & 16 hari & $8,00 \pm 0,819^{b}$ \\
\hline & & 18 hari & $8,00 \pm 0,819^{b}$ \\
\hline \multirow{7}{*}{4} & \multirow{7}{*}{$\begin{array}{l}\text { Kombinasi Air Rebusan Daun } \\
\text { Sirih dan Kayu Siwak } 70 \% \\
\left.\text { (suhu dingin, } 0-8{ }^{\circ} \mathrm{C}\right)\end{array}$} & 0 hari & $26,75 \pm 1,258^{\mathrm{c}}$ \\
\hline & & 2 hari & $20,25 \pm 0,500^{c}$ \\
\hline & & 5 hari & $17,50 \pm 1,732^{\mathrm{c}}$ \\
\hline & & 7 hari & $16,25 \pm 0,500^{c}$ \\
\hline & & 9 hari & $15,75 \pm 0,500^{c}$ \\
\hline & & 11 hari & $15,75 \pm 0,500^{\mathrm{c}}$ \\
\hline & & 14 hari & $14,50 \pm 0,574^{\mathrm{c}}$ \\
\hline
\end{tabular}




$\begin{array}{ll}16 \text { hari } & 9,75 \pm 0,500^{\mathrm{b}} \\ 18 \text { hari } & 9,75 \pm 0,500^{\mathrm{b}}\end{array}$

Keterangan: angka yang diikuti dengan huruf yang sama pada kolom yang sama menunjukkan tidak berbeda nyata $(n=5, p>0,05)$

Tabel 4. Analisis T Test terhadap ragam penyimpanan

\begin{tabular}{ccccccc}
\hline \multicolumn{2}{c}{ Ragam penyimpanan } & $\mathbf{N}$ & Mean & Std. Deviation & Std. Error Mean \\
\hline \multirow{2}{*}{$\begin{array}{c}\text { Diameter zona } \\
\text { hambat }\end{array}$} & Suhu ruang & 108 & 4,8333 & 7,55602 & 0,72708 \\
\cline { 2 - 7 } & suhu dingin & 108 & 5,4167 & 8,21456 & 0,79045 \\
\hline & \multicolumn{3}{c}{$\begin{array}{c}\text { Levene's Test for } \\
\text { Equality of Variances }\end{array}$} & \multicolumn{2}{c}{ t-test for Equality of Means } \\
\cline { 2 - 7 } & $\mathrm{F}$ & Sig. & $\mathrm{T}$ & $\mathrm{df}$ & Sig. (2-tailed) \\
\hline $\begin{array}{c}\text { Diameter } \\
\text { zona } \\
\text { bening }\end{array}$ & $\begin{array}{c}\text { Equal variances } \\
\text { assumed }\end{array}$ & 2.177 & .142 & -.543 & 214 & .588 \\
\cline { 2 - 7 } & $\begin{array}{c}\text { Equal variances } \\
\text { not assumed }\end{array}$ & & & -.543 & 212.523 & .588 \\
\hline
\end{tabular}

Keterangan:

Nilai hasil uji levene test untuk homogenitas, yaitu homogen. Maka baris pertama yang digunakan, yaitu nilai t hitung 0,543 pada DF 214. Nilai t hitung dibandingkan dengan t tabel pada DF 214 dengan probabilitas 0,05 . Nilai sig ( 2 tailed) atau $\mathrm{p}$ value sebesar 0,588 yaitu >0,05, maka perbedaan tidak bermakna secara statistik atau tidak signifikan pada probabilitas 0,05. Besar perbedaan rerata kedua kelompok ditunjukkan pada kolom mean difference, yaitu -0,58333. Nilai negatif artinya kelompok pertama memiliki rerata lebih rendah dari pada kelompok kedua.

\section{PEMBAHASAN}

Uji Hambat Minimum. Uji hambat minimum dilakukan untuk menentukan konsentrasi terendah yang mampu menghambat pertumbuhan bakteri Streptococcus mutans. Hasil menunjukkan bahwa semakin tinggi konsentrasi kombinasi air rebusan daun sirih dan kayu siwak maka semakin luas zona bening yang terbentuk (Tabel 2).

Tabel 2 menunjukkan kelompok perlakuan kombinasi air rebusan dengan konsentrasi $10-60 \%$ tidak berbeda nyata terhadap kelompok kontrol negatif dan kontrol positif. Sedangkan, kelompok perlakuan kombinasi air rebusan dengan konsentrasi $70 \%$ berbeda nyata dibandingkan kontrol. Diameter zona hambat kombinasi air rebusan dengan konsentrasi $70 \%$ sebesar 27,33 $\pm 0,577$. Berdasarkan hasil penelitian Enayati (2010) menunjukkan bahwa antibiotik amoxicillin membentuk zona hambat dengan diameter hambatan sebesar 24,66 $\mathrm{mm}$ terhadap Streptococcus mutans. Aktivitas penghambatan kombinasi air rebusan daun sirih dan kayu siwak dengan konsentrasi $70 \%$ lebih besar dibandingkan dengan antibiotik amoxicillin. Kontrol positif obat kumur komersial dan kontrol negatif (akuades) tidak menunjukkan zona hambat terhadap bakteri Streptococcus mutans. Hal ini sejalan dengan hasil penelitian Hamrun dan Anam (2012) tentang uji penghambatan obat kumur komersial terhadap bakteri Streptococcus mutans.

Hasil penelitian menunjukkan bahwa diameter zona hambat kelompok perlakuan akuades, obat kumur komersial yang mengandung alkohol; povidon iodine; benzydamin HCL; dan hexatidine, berturutturut, yaitu $0 ; 0 ; 0 ; 5,61$; dan 12,63. Alkohol memiliki sifat bakteriosida, biasanya digunakan pada konsentrasi di atas 50\%. Sedangkan konsentrasi alkohol pada obat kumur komersial sebesar 21,6\%. Rendahnya konsentrasi alkohol disebabkan adanya bahan tambahan lain dalam obat kumur seperti air, benzoic acid, poloxamer 407, eucalyptol, thymol, methyl salicylate, nebthol, caramel, sodium hydroxide, hydrochloric acid (Hamrun dan Anam, 2012). 
Uji Hambat Streptococcus mutans dengan Ragam Penyimpanan. Penyimpanan merupakan upaya berupa tindakan pengamanan komoditas yang karena sesuatu keadaan atau tujuan harus ditahan untuk beberapa waktu, dengan menghindari, mengurangi atau menghilangkan berbagai faktor yang dapat mengurangi nilai komoditas. Selama proses penyimpanan dapat terjadi kehilangan/ penurunan mutu komoditas. Upaya yang dapat dilakukan pada kondisi penyimpanan, antara lain penyimpanan alami dan penyimpanan terkendali. Penyimpanan terkendali dilakukan dengan penyimpanan pada suhu rendah (freezer) (Soesarsono, 2008).

Ragam/ jenis penyimpanan yang dilakukan pada penelitian ini adalah penyimpanan alami dan penyimpanan pada suhu rendah, yaitu disimpan dalam suhu ruang $\left(25 \pm 1^{\circ} \mathrm{C}\right)$ dan suhu dingin $\left(0-8^{\circ} \mathrm{C}\right)$. Kombinasi air rebusan ditempatkan dalam botol steril yang ditutup rapat, dimana penuangan dilakukan secara aseptis.

Uji hambat dilakukan untuk mengetahui adanya perbedaan dan penurunan mutu dari sediaan herbal kombinasi air rebusan daun sirih dan kayu siwak, khususnya mutu penghambatan mikroba.

Tabel 3 menunjukkan bahwa terdapat perbedaan rerata diameter zona hambat kombinasi air rebusan daun sirih dan kayu siwak yang disimpan dalam suhu ruang dan suhu dingin. Rerata diameter zona hambat dengan ragam penyimpanan pada suhu dingin $\left(0-8^{\circ} \mathrm{C}\right)$ lebih tinggi terhadap suhu ruang. Berdasarkan hasil analisis independent $T$ test, menunjukkan perbedaan yang tidak bermakna, nilai $\mathrm{p}$ value $=0,588$ ( $\mathrm{p}$ value $>0,05)$.

Uji Hambat Bakteri dengan Ragam Periode Penyimpanan. Kombinasi air rebusan daun sirih dan kayu siwak sebagai sediaan herbal, merupakan suatu produk olahan, dimana memiliki umur simpan. Pengertian umur simpan yaitu waktu yang diperlukan produk olahan dalam kondisi penyimpanan tertentu untuk dapat mencapai tingkatan degradasi mutu tertentu. Jika melewati waktu tersebut, produk dapat dikatakan tidak layak digunakan. Hal ini dikarenakan produk mengalami perubahan baik fisika, kimia maupun mikrobiologis seperti kenampakan dan cita rasa. Perubahanperubahan tersebut akan menurunkan tingkat kegunaan produk tersebut dan akan diperburuk dengan cara penyimpanan yang salah. Apabila kombinasi air rebusan daun sirih dan kayu siwak sebagai produk obat kumur, disimpan dalam kurun waktu lama, diduga mengalami penurunan tingkat kegunaannya. Satu parameter tingkat kegunaan yang akan diamati pada penelitian ini adalah daya hambat terhadap Streptococcus mutans, bakteri penyebab karies gigi.

Tabel 4 menunjukkan bahwa terjadi penurunan nilai diameter zona hambat selama penyimpanan. Hal ini berarti mutu penghambatan mikroba kombinasi air rebusan daun sirih dan kayu siwak berkurang selama proses penyimpanan. Berkurangnya diameter zona hambat yang terbentuk pada periode penyimpanan 0 sampai dengan 14 hari tidak berbeda nyata. Sedangkan diameter zona hambat yang terbentuk pada periode penyimpanan 16 dan 18 hari berbeda nyata terhadap periode penyimpanan 0 hari. Maka umur simpan sediaan herbal kombinasi air rebusan daun sirih dan kayu siwak adalah 14 hari, karena setelah 14 hari, tidak memberikan mutu penghambatan mikroba yang sama.

Pratiwi dan Muderawan (2016) menyatakan bahwa terdapat 31 senyawa yang terkandung dalam daun sirih hijau, dengan kandungan utama yaitu eugenol (25.03\%); asam 2,5dimetilbenzoat (12.08\%); dekahidro4a-metil-1-metilenyl naftalena (7.18\%); $1,2,3,4,4 a, 5,6,8$ a-oktahidro-7-metil naftalena $(8.36 \%)$; dan 1,2,3,4, 4a,5,6,8a-oktahidro4ametilnaftalena (13.43\%). Hasil ini menunjukkan bahwa mayoritas senyawa aktif dari ekstrak sirih hijau adalah golongan fenolik yang mempunyai aktivitas antibakteri.

Senyawa fenolik juga diketahui memiliki berbagai efek biologis seperti aktivitas antioksidan melalui mekanisme sebagai pereduksi, penangkap radikal bebas, pengkelat logam, peredam terbentuknya singlet oksigen serta pendonor elektron (Karadeniz et al, 2005). Efek biologis senyawa fenolik seperti antibakteri dan antioksidan dipengaruhi oleh 
lama penyimpanan. Penelitian sejenis oleh Pratiwi (2015) menunjukkan nilai aktivitas antioksidan tertinggi minuman fungsional umbi bawang dayak formula sereh ialah pada penyimpanan hari ke-0 yaitu 53,9\%, sedangkan nilai aktivitas antioksidan terendah di dapatkan pada penyimpanan hari ke-12 yaitu $36,2 \%$.

Sifat Kimia dan Fisik Kombinasi Air Rebusan Daun Sirih dan Kayu Siwak Pasca Penyimpanan. Komoditas dapat mengalami kehilangan mutu fisik dan kimia selama proses penyimpanan. Fisik komoditas mempengaruhi ketertarikan konsumen untuk memanfaatkan komoditas tersebut, salah satunya adalah warna komoditas.

Setelah penyimpanan selama 18 hari, warna sediaan herbal kombinasi air rebusan daun sirih dan kayu siwak terdapat perbedaan antara penyimpanan suhu ruang dan suhu dingin. Cairan kombinasi air rebusan yang disimpan pada suhu ruang berwarna kuning kecoklatan, sedangkan yang disimpan pada suhu dingin $\left(0-8^{\circ} \mathrm{C}\right)$ berwarna kuning kehijauan. Hal ini juga sejalan dengan penelitian oleh Mastuti $d k k$. (2013), intensitas ekstrak bunga Telang berbeda antara penyimpanan dalam suhu dingin dibandingkan suhu kamar. Perubahan nilai absorbansi terbesar terjadi pada ekstrak yang disimpan pada suhu kamar dan perubahan tidak signifikan pada ekstrak yang disimpan pada suhu dingin. Perubahan intensitas warna disebabkan oleh reaksi kopigmentasi dan diduga ekstrak masih mengandung enzim polifenolase (Lydia $d k k .$, 2001). Kerja enzim dipengaruhi oleh kondisi lingkungan, salah satunya adalah suhu yang dapat menghambat kerja enzim apabila berada pada diluar suhu optimumnya. Demikian juga dengan enzim polifenolase yang terhambat aktivitasnya karena berada pada lingkungan dengan temperatur di bawah suhu optimum aktivitasnya. Hal ini menyebabkan zat warna pada kombinasi air rebusan mengalami perubahan, namun tidak signifikan.

Selain warna, sifat fisik lain yang dilakukan adalah pengukuran $\mathrm{pH}$ cairan kombinasi air rebusan setelah penyimpanan selama 18 hari. Hasil menunjukkan bahwa rerata $\mathrm{pH}$ kombinasi air rebusan baik yang disimpan pada suhu ruang maupun suhu dingin adalah 5 (lima), cenderung bersifat asam. Asam-asam organik dapat terbentuk selama proses penyimpanan yang dapat menurunkan $\mathrm{pH}$. Hal ini juga dengan pendapat Young (2002), bahwa perubahan nilai $\mathrm{pH}$ akan terpengaruh oleh media yang terdekomposisi oleh suhu tinggi saat pembuatan atau penyimpanan yang menghasilkan asam atau basa.

\section{KESIMPULAN}

Kombinasi air rebusan daun sirih dan kayu siwak dapat disimpan pada suhu dingin (0$8^{\circ} \mathrm{C}$ ) dan suhu ruang agar mempertahankan daya hambatnya terhadap pertumbuhan Streptococcus mutans. Hasil analisis independent $T$ test, menunjukkan perbedaan yang tidak bermakna antara penyimpanan suhu dingin dan suhu ruang, nilai $\mathrm{p}$ value $=0,588$. Periode penyimpanan kombinasi air rebusan daun sirih dan kayu siwak adalah 14 hari, hasil analisis LSD menunjukkan perbedaan yang tidak bermakna selama penyimpanan sampai dengan 14 hari, nilai $\mathrm{p}$ value $=0,250$. Perubahan bermakna daya hambat kombinasi air rebusan daun sirih dan kayu siwak dengan konsentrasi $70 \%$, terhadap pertumbuhan Streptococcus mutans yaitu pada penyimpanan 16 dan 18 hari, nilai p value $=0,009$.

Perlunya penelitian lanjut dalam pemanfaatan kombinasi air rebusan daun sirih dan kayu siwak sebagai kandidat obat kumur alami yang dibuat dalam sediaan herbal, sehingga perlu uji publik tentang parameter organoleptik dan pengaruhnya terhadap kesehatan rongga mulut

\section{UCAPAN TERIMA KASIH}

Kegiatan penelitian didanai oleh DIPA Poltekkes Tanjungkarang pada skema Hibah Calon Dosen 2016, maka diucapkan terimakasih atas persetujuan dana oleh Direktur Poltekkes Tanjungkarang. Juga terima kasih dan penghargaan yang sebesarbesarnya kepada Kepala Laboratorium Kesehatan Daerah Provinsi Lampung dan segenap pihak yang telah berkontribusi dalam kelancaran pelaksanaan penelitian ini. 


\section{DAFTAR PUSTAKA}

Adrianto AWD. 2012. Uji Daya Antibakteri Ekstrak Daun Salam (Eugenia polyanthawight) dalam Pasta Gigi Terhadap Pertumbuhan Streptococcus Mutans. [Skripsi]. Jember: Fakultas Kedokteran Gigi, Unversitas Jember.

Chopra RN, Nayar SL, Chopra IC. 1956. Glossary of Indian Medicinal Plants. New Delhi: CSIR. pp.194.

DEPKES RI. 1980. Materia Medika Indonesia Jilid IV Cetakan Pertama. Jakarta: Dirjen Pengawasan Obat dan Makanan.

Djais A and Tope V. 2017. Effectiveness of siwak salvadora persica extract to Aggregatibacter actinomycetemcomitans as one of pathogenic bacteria causing periodontal disease. Journal of Dentomaxillofacial Science. vol 2(1): 3539. doi:10.15562/jdmfs.v2i1.449.

Enayati D. 2010. Uji Anti Mikroba Ekstrak Metanol Bunga Cengkeh Terhadap Bakteri Penyebab Karies Gigi, Streptococcus mutans. [Skripsi]. Jurusan Biologi FMIPA Universitas Sumatera Utara.

Hamrun N dan Anam MN. 2012. Uji Daya Hambat Obat Kumur Terhadap Pertumbuhan Streptococcus Mutans. Makassar Dental Journal. vol 1(5): 1-5.

Karadeniz F, Burdurlu HS, Koca N, Soyer Y. 2005. Antioxidant Activity of Selected Fruits and Vegatables Grown in Turkey. Turk. J. Agric For. vol 29(2005): 297-303. Lydia SW, Widjanarko SB, Susanto T. 2001. Ekstraksi dan Karakterisasi Pigmen dari Kulit Buah Rambutan (Nephelium Lappaceum) var. Binjai. Biosain. vol 1(2): 42-53.
Mastuti E, Fristianingrum, Godeliva, Andika Y. 2013. Ekstraksi dan Uji Kestabilan Warna Pigmen Antosianin Dari Bunga Telang (Clitoria ternatea L.) Sebagai Bahan Pewarna Makanan. Simposium Nasional RAPI XII-2013 FT UMS ISSN 1412-9612.

Pratiwi NPRK. dan Muderawan IW. 2016. Analisis Kandungan Kimia Ekstrak Daun Sirih Hijau (Piper betle) dengan GC-MS. [Prosiding Seminar Nasional MIPA]. Singaraja: Universitas Pendidikan Ganesha. hal 304-307.

Pratiwi R. 2015. Pengaruh Suhu Dan Waktu Penyimpanan Terhadap Aktivitas Antioksidan Minuman Fungsional Umbi Bawang Dayak Formula Sereh. [Tugas Akhir]. Samarinda: Program Studi Teknologi Pengolahan Hasil Perkebunan Politeknik Pertanian Negeri Samarinda.

Rispler-chaim, Vardit. 1992. The Siwak: A Medieval Islamic Contribution to Dental Care. Journal of The Royal Asiatic Society vol 2(1): 13-20. doi.org/10.1017/S135618630000177.

Soesarsono W. 2008. Penyimpanan dan Penggudangan. Jakarta: Universitas Terbuka. ISBN 9796899418

Sumiati, E. 2014. Uji Aktivitas Antibakteri Ekstrak Kloroform dan Ekstrak Etanol Biji Bidara Laut (Strychnos ligustrina Bl) Terhadap Staphylococcus aureus ATCC 25923 dan Salmonella thypi. Biogenesis 2(1): 1-10. doi.org/10.24252/bio.v2i1.461

Young A. 2002. Practical Cosmetic Science. London: Mills and Boon Limited. pp. 3940 . 